\title{
Penerapan Teknologi Radio Frequency Identification (RFID) Pada Data Kunjungan Perpustakaan
}

\author{
Rifki Maulana Insan ${ }^{1}$, Ruuhwan ${ }^{2}$, Randi Rizal ${ }^{3}$ \\ ${ }^{1,2,3}$ Teknik Informatika, Fakultas Teknik, Universitas Perjuangan, Jalan PETA No. 177 Kota Tasikmalaya \\ rifki@unper.ac.id ${ }^{1}$,ruuhwan@unper.ac.id ${ }^{2}$,randirizal@unper.ac.id ${ }^{3}$
}

\begin{tabular}{ll}
\hline INFORMASI ARTIKEL & A B S T R A K \\
\hline Sejarah Artikel: & RFID (Radio Frequenscy Identification) merupakan sebuah teknologi compact wireless \\
Diterima Redaksi : - & yang diunggulkan untuk mentranformasi dunia komersial. Telah banyak dikembangkan di \\
Revisi Akhir : - & dunia bisnis maupun keamanan dewasa ini sebagai suksesor dari barcode, RFID dapat \\
Diterbitkan Online : - & melakukan control otomatis untuk banyak hal. Sistem-sistem RFID menawarkan \\
& peningkatan efisien dalam penggendalian inventory control dalam pengidentifikasian \\
\hline Kata Kunci: & barang. Oleh karena itu terdapat manfaat yang besar untuk sebuah perpustakaan secara \\
RFID, Perpustakaan, Data Kunjungan, & intensif mempercayakan pada sistem ini. Adopsi yang meluas dari RFID banyak \\
Arduino Uno, IoT. & memunculkan persoalan dalam peningkatan layanan khususnya layanan self-service dan \\
& mengurangi layanan contacless, jaminan keamanan buku di perpustakaan sehingga \\
\hline Korespondensi : & perpustakaan akan dapat mengoptimalkan sumber daya manusia di perpustakaan. Peneliti \\
Telepon / Hp : +62 85320132014 & menerapkan teknologi RFID pada pengisian data kunjungan perpustakaan dengan \\
E-mail : randirizal@unper.ac.id & menggabungkan teknologi RFID yang berfungsi sebagai penghubung antara RFID reader \\
& dengan pembacaan database berbasis arduino.
\end{tabular}

\section{PENDAHULUAN}

Data kunjungan perpustakaan merupakan salah satu faktor penting dalam keamanan perpustakaan, informasi yang di dapat diantaranya nama, kelas dan waktu kunjungan. Tetapi terkadang fungsi data kunjungan perpustakaan dapat dimanipulasi identitas, Hal ini terjadi karena data kunjungan perpustakaan yang masih menggunakan pengisian data manual.

Membantu mengatasi permasalahan tersebut beberapa penelitian telah dilakukan oleh Ria Widyawati, 2013 [1]. Pada penelitian ini peneliti membuat Sistem informasi perpustakaan dan data kunjungan dengan menggunakan Barcode yang berisi aplikasi input data anggota dan input buku perpustakaan dengan menggunakan barcode. Dilengkapi aplikasi untuk transaksi peminjaman dan pengembalian buku dengan memanfaatkan barcode. Tahun 2015, Husin Nanda Perwira [2] membahas tentang pembuatan sistem informasi perpustakaan yang terdapat data kunjungan perpustakaan berbasis web. Pada penelitian tahun 2017 [3], peneliti membuat sistem informasi perpustakaan dan data kunjungan dengan menggunakan Qrcode.

Berdasarkan analisis peneliti masih memiliki beberapa kelemahan seperti dimana data dapat dimanipulasi qrcode yang sangat mudah di duplikasi. Oleh karena itu pada penelitian ini peneliti mencoba untuk merancang data kunjungan dengan konsep Internet Of Think menggunakan modul Radio Frequenscy Identification (RFID) dapat melengkapi penelitian sebelumnya. Disisi lain Radio Frequency Identification (RFID) dewasa ini berkembang sangat pesat. Teknologi identifikasi ini banyak digunakan di berbagai bidang untuk membantu dalam pengidentifikasian suatu objek sebagai pengganti.
Diantaranya aplikasi dari teknologi Radio Frequenscy Identification (RFID) dapat dijumpai pada kartu jalan tol, kartu parkir, maupun kartu daftar hadir pegawai. Untuk membantu mengatasi permasalahan diatas, Peneliti mencoba menerapkan teknologi Radio Frequenscy Identification (RFID) pada pengisian data kunjungan perpustakaan berbasis Internet of Things (IoT).

\section{LANDASAN TEORI}

\subsection{Internet Of Things}

Menurut Ashton Kevin (2009) [4], Internet Of Things (IoT) didefinisikan sebagai sebuah teknologi yang memungkinkan adanya pengendalian, komunikasi, kerja sama dengan berbagai perangkat keras, berbagi data, memvirtualisasikan segala hal nyata ke dalam bentuk internet, dan lain - lain, melalui jaringan internet. Disebut juga M2M (Machine to Machine).

Pada hakekatnya benda internet atau Internet $O f$ Things (IoT) mengacu pada benda yang dapat diidentifikasikan secara unik sebagai representasi virtual dalam struktur berbasis internet. Istilah Internet Of Things (IoT) awalnya disarankan oleh Kevin Asthon pada 1999 dan mulai populer melalui Auto-ID Center di Massachusetts Institute of Technology (MIT).

\subsection{Perpustakaan}

Menurut Bafadal (2014) Perpustakaan adalah suatu unit kerja dari suatu badan atau lembaga tertentu yang mengelola bahan-bahan pustaka, baik berupa buku-buku maupun bukan berupa buku (non book material) yang diatur secara sistematis menurut aturan tertentu sehingga dapat digunakan sebagai sumber informasi oleh setiap pemakainya. 


\subsection{Sistem}

Dalam penelitian [6] Sistem adalah suatu jaringan kerja dari beberapa prosedur yang saling berhubungan, berkumpul bersama-sama untuk melakukan suatu kegiatan atau menyelesaikan suatu tujuan tertentu. Pengertian lain dari sistem adalah kumpulan beberapa elemen yang berinteraksi untuk mencapai tujuan tertentu. Selain dari yang dijelaskan di atas, komponenkomponen yang ada pada suatu sistem juga saling bergantung satu dengan yang lain, serta komponenkomponen tersebut terlihat sebagai satu kesatuan yang utuh dan memiliki kestabilan.

\subsection{RFID}

Sejarah perkembangan radio frequency identification (RFID) dimulai sejak tahun 1920, tetapi berkembang menjadi IFF transponder pada tahun 1939. Yang waktu itu berfungsi sebagai alat identifikasi pesawat musuh, dipakai oleh militer Inggris pada perang dunia II. Sejak tahun 1945 beberapa orang berfikir bahwa perangkat pertama RFID ditemukan oleh Leon Theremin sebagai suatu tool spionase untuk pemerintahan Rusia. RFID adalah sebuah teknologi yang menggunakan frekuensi radio untuk mengindentifikasi suatu barang atau manusia.

Menurut Kania (2011) [8], sistem RFID terbagi menjadi 3 komponen, yaitu : RFID Tag, RFID Terminal Reader, dan Middleware. Sedangkan untuk jenisnya RFID terbagi, berdasarkan frekuensi, berdasarkan sumber energi, dan berdasarkan bentuk. Penerapan RFID sudah digunakan di berbagai jenis perpustakaan. Mulai dari perpustakaan perguruan tinggi, perpustakaan daerah, perpustakaan sekolah dan jenis perpustakaan lainnya. Adapun kelebihan dari sistem RFID tersebut adalah sistem inventori berkecepatan tinggi, proses sirkulasi yang cepat, penanganan buku-buku secara otomatis. RFID mampu membaca suatu objek data dengan ukuran tertentu tanpa melalui kontak langsung (contacless) dan tidak harus sejajar dengan objek yang dibaca, selain dapat menyimpan informasi pada tag RFID sesuai dengan kapasitasnya penyimpanan tarigan.

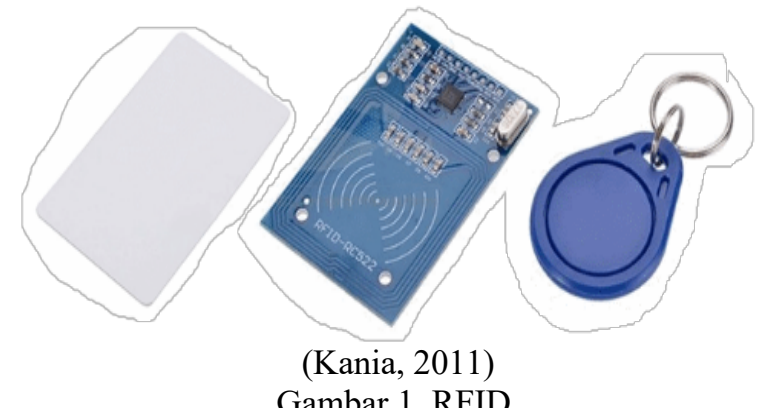

Gambar 1. RFID

\section{DESAIN SISTEM}

Sistem Data Kunjungan Perpustakaan yang dikembangkan melibatkan hardware dan software. Sistem dirancang untuk dapat melakukan pengendalian terhadap data kunjungan melalui aplikasi data kunjungan perpustakaan yang terbubung dengan jaringan internet. Teknologi RFID memungkinkan pengguna dapat mengisi data kunjungan secara efisien dengan jarak yang cukup jauh dengan computer server. secara umum arsitektur sistem yang dikembangkan ditampilkan pada gambar 2 .

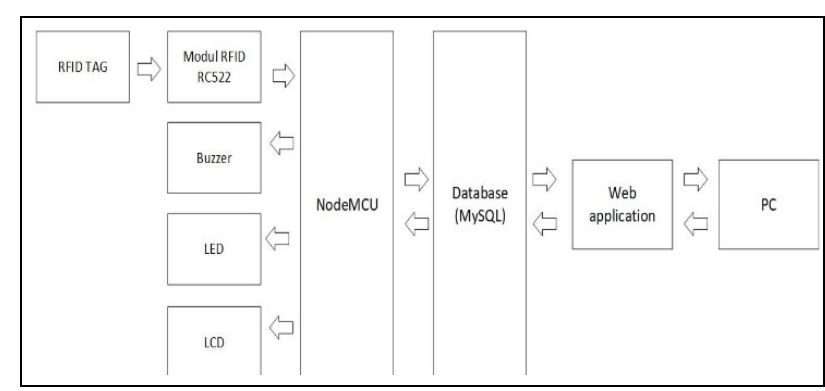

Gambar 2. Blok Diagram

Arsitektur sistem yang dibangun seperti pada Fig 1, melibatkan sembilan komponen hardware utama :

1. NodeMCU berfungsi sebagai sistem yang memanifulasi,mengeksekusi, memonitor proses kerja alat dan berfungsi sebagai penyambung antara Rfid dan internet, NodeMCU menggabungkan antara Arduino dan Modul Esp8266.

2. Modul Rfid berfungsi sebagai alat pembaca data dari tag.

3. Rfid Tag berfungsi sebagai Id.

4. Buzzer digunakan untuk memberikan informasi berupa bunyi.

5. LED digunakan untuk memberikan informasi berupa Cahaya.

6. LCD digunakan untuk memberikan informasi tampilan text

7. Database Digunakan sebagai pengimpan data dari Rfid.

8. Web application Digunakan sebagai control aplikasi

9. Pc digunakan sebagai akses control web

Selain dari hardware, juga dibutuhkan software untuk pengembangan Sistem. Spesifikasi software yang digunakan dalam pengembangan aplikasi ditampilkan pada Tabel I.

TABEL 1. SPESIFIKASI SOFTwARE

\begin{tabular}{cll}
\hline No & Software & Version \\
\hline $\mathbf{1}$ & Visual Studio Code & 1.38 .1 \\
\hline $\mathbf{2}$ & Arduino IDE & 1.8 .9 \\
\hline $\mathbf{3}$ & Xampp & 3.2 .4 \\
\hline
\end{tabular}

Tahapan berikutnya membuat rancangan sistem Input dan Output yang dapat melakukan komunikasi antara pengunjung dan aplikasi Data kunjungan perpustakaan. Komunikasi antara aplikasi dan mikrokontroller dilakukan dengan cara mengirim (post) di url dan mengambil data (get) di url yang telah disediakan oleh web. Secara umum alur sistem 
kunjungan perpustakaan dijelaskan dalam bentuk flowchart pada gambar 3.

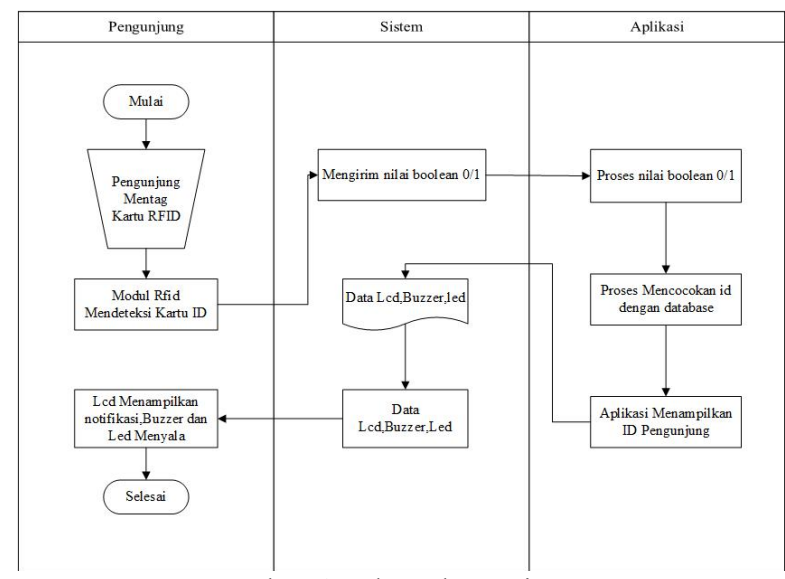

Gambar 3. Flowchart Sistem

Adapun output yang ditampilkan oleh server web yaitu berupa program PHP yang nantinya akan di translate ke sistem yang langsung diteruskan ke mikrokontroller Arduino (NodeMCU) yang mempunyai jenis input dan output berupa sinyal digital dan sinyal analog. Terakhir web server akan memeriksa apakah pengunjung mentag RFID card,Jika Mikrokontroler mendeteksi kartu RFID maka web server akan menampilkan ID dari kartu. Jika belum terdaftar web akan menampilkan ID di form Daftar.

Setelah rancangan selesai dibuat maka, tahap berikutnya dilakukan implementasi atau pengembangan sistem. Alur Sistem Data Kunjungan Perpustakaan ditampilkan pada gambar 4 .

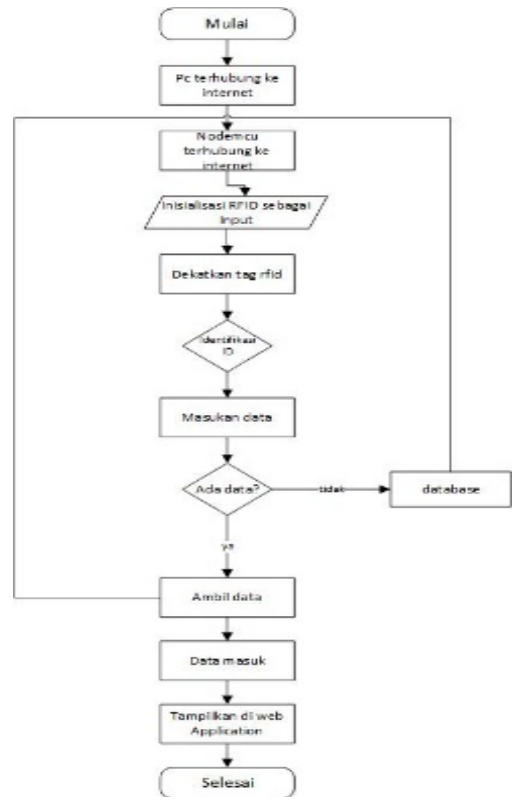

Gambar 4. Diagram Alur Sistem

Pada gambar 4 ditampilkan tahapan penggunaan aplikasi secara umum. Langkah awal pastikan hardware mikrokontroller dan $P c$ sudah terhubung ke internet. Nyalakan xampp untuk mengakses web di localhost yang akan digunakan oleh pengguna. Tahap pertama
Tag RFID yang belum terdaftar di database, kemudian pilih Form Daftar dan isi sesuai data (nama, nim, kelas, angkatan) dan pilih Add. Tahap berikutnya pilih menu utama dan tag kembali kartu RFID ke sensor maka akan menampilkan kunjungan anda sesuai tanggal dan jam masuk.

Pada gambar 5 ditampilkan sistem secara keseluruhan yang didalamnya terdapat mikrokontroller Arduino (NodeMCU) yang digunakan untuk memproses data-data masukan dan keluaran dari tiap modul dan sensor.

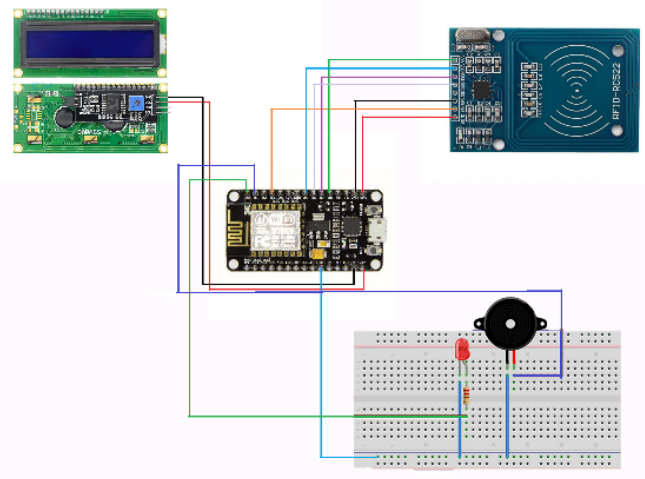

Gambar 5. Rangkaian Sistem

\section{HASIL DAN PEMBAHASAN}

Terdapat empat tahap utama yang dilakukan pada percobaan dalam penelitian ini yaitu : hardware preparation, network configuration, install and runing kunjungan perpustakaan app, testing.

\section{A. Hardware preparation}

Pada tahap ini dilakukan identifikasi kebutuhan hardware yang diperlukan pada implementasi sistem kunjungan perpustakaan. Hardware yang digunakan meliputi arduino (NodeMCU), Modul RFID (rc522), LCD, LED, Buzzer dan PC. Selain itu juga dibutuhkan access internet untuk menghubungkan NodeMCU dan jaringan internet. Spesifikasi hardware yang digunakan ditampilkan pada Tabel III.

TABEL II. HARDWARE SPECIFICATION

\begin{tabular}{lll}
\hline No & Item & Description \\
\hline $\mathbf{1}$ & $\begin{array}{l}\text { Personal } \\
\text { Komputer }(P C)\end{array}$ & $\begin{array}{l}\text { - CPU: Core i3 } \\
\text { - Memory: } 2 \mathrm{~GB} \\
\text { - OS: Windows 10 Pro } \\
\text { - SSD:120 GB }\end{array}$ \\
\hline $\mathbf{2}$ & NodeMCU & $\begin{array}{l}\text { - ESP8266 } \\
\text { - Tegangan Input: } 3.3 \sim 5 \mathrm{~V} \\
\text { - Flash memori: } 4 \mathrm{mb}\end{array}$ \\
\hline $\mathbf{4}$ & RFID & $\begin{array}{l}\text { - Tegangan Input: 3.3V. } \\
\text { - Transfer Rate max: } 10 \mathrm{Mbit} / \mathrm{s}\end{array}$ \\
\hline $\mathbf{5}$ & Lcd & - Voltage 5(vdc \\
\hline $\mathbf{6}$ & Led & - Output : analog \\
\hline $\mathbf{7}$ & Buzzer & - Voltage 5(vdc \\
\hline
\end{tabular}




\section{B. Network Configuration}

Pada pengaturan jaringan, Mikrokontroler harus di program sesuai dengan wifi yang tersedia dari memasukan ssid,password dan ip address. Percobaan pada penelitian ini dilakukan pada jaringan internet dari ISP provider. Untuk hardware mikrokontroller dikoneksikan dengan Access point dikonfigurasi sebagai static server, sehingga client mendapatkan IP address secara static dan terhubung pada internet.

\section{Install and runing Data Kunjungan Perpustakaan}

Pada bagian ini dilakukan instalasi aplikasi Data kunjungan pada Personal Komputer pengguna. Tahap awal yang harus dilakukan adalah hidupkan xampp pada pc sehingga web dapat berjalam, pengguna tidak direpotkan saat penggunakan aplikasi ini.

Setelah aplikasi Data kunjungan dijalankan seperti pada gambar 6 , kemudian pilih form daftar bagi kartu yang belum terdaftar di data base maka akan langsung di arahkan ke form daftar isi sesuai data diri.

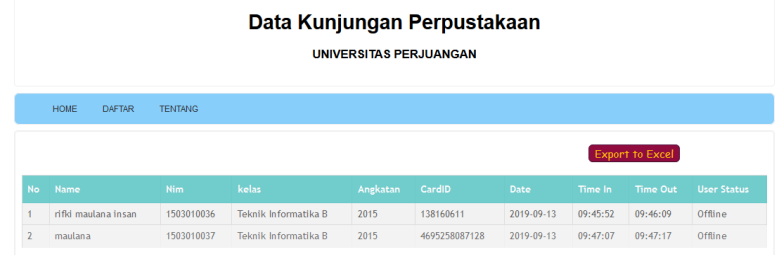

Gambar 6. Screen Home

Tahap percobaan pertama menjalankan perintah Daftar RFID card, Tahapan ini RFID card yang belum terdaftar di database, akan di daftar sesuai data diri, pada gambar 7 .

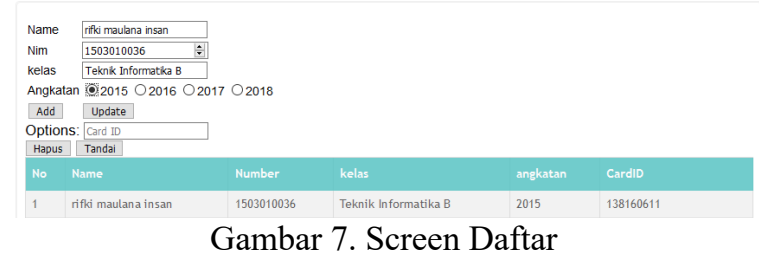

Tahap selanjutnya menjalankan perintah tag RFID yang sudah terdaftar maka secara otomatis web akan menampilkan kunjungan pada tanggal dan waktu sesuai saat mentag RFID. Tampilan Tag RFID dapat dilihat pada tampilan gambar 8 .

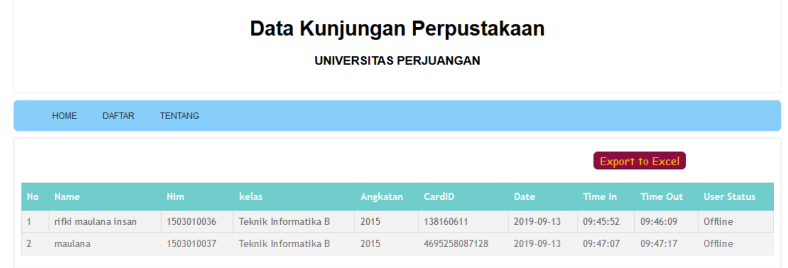

Gambar 8. Screen Tag RFID

Tahap selanjutnya menjalankan Perintah Export ke excel. Pada percobaan ini otomatis ketika menekan button export secara otomatis browser akan menampilkan download file seperti pada tampilan gambar 9.

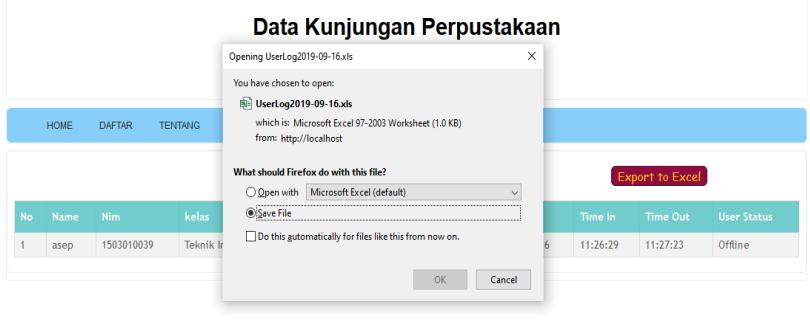

Gambar 9. Screen Export to Excel

\section{Pengujian}

1. Pengujian Sistem

Setelah aplikasi Data Kunjungan Perpustakaan dijalankan, pada percobaan ini sistem dalam kondisi stanby dan terkoneksi ke internet. Tampilan hasil percobaan ditampilkan pada gambar 10.

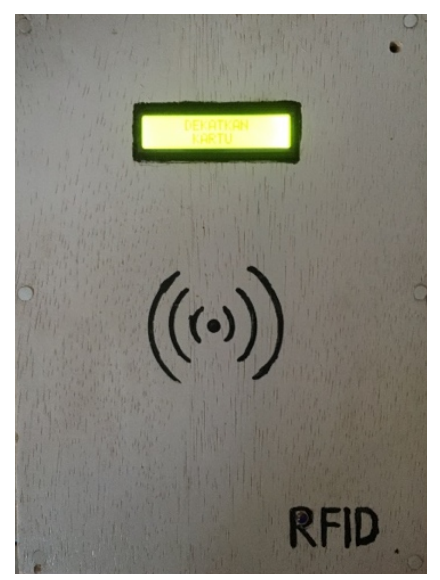

Gambar 10. Screen system stanby

Selanjutnya, percobaan dilakukan dengan mentag RFID. Tampilan hasil percobaan dapat dilihat pada gambar 11.

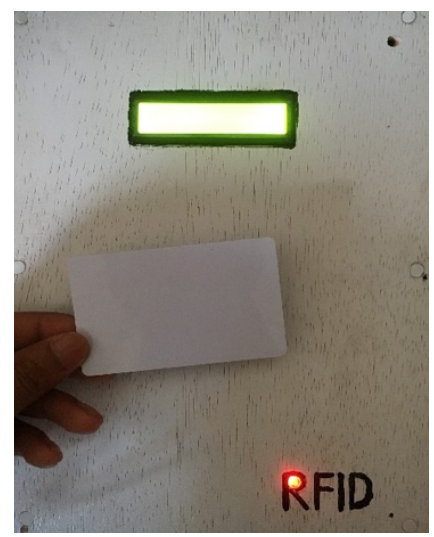

Gambar 11. Screen Tag RFID

Berikutnya, percobaan. Hasil percobaan mentag RFID kedua kali dengan kartu id yang sama akan lcd 
Rifki Maulana Insan, dkk, Radio Frequency Identification ... 5

menampilkan text berupa "terimakasih telah berkunjung”, dapat dilihat pada gambar 12 .

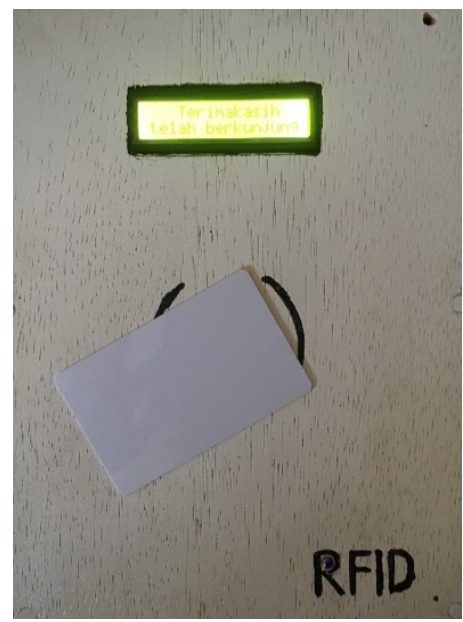

Gambar 12. Screen Tag RFID Out

\section{Hasil Pengujian Sistem}

Pada bagian ini disajikan hasil percobaan pada sistem Data Kunjungan Perpustakaan. Seperti yang dapat dilihat pada Table III.

TABEL III. PENGUJIAN FORM DAFTAR

\begin{tabular}{|c|c|c|c|c|}
\hline Percobaan & $\begin{array}{l}\text { Jenis } \\
\text { Pengujian }\end{array}$ & $\begin{array}{l}\text { Yang } \\
\text { diharapkan }\end{array}$ & Pengamatan & Hasil \\
\hline 1. & $\begin{array}{l}\text { Kartu Rfid } \\
\text { yang } \\
\text { belum } \\
\text { terdaftar } \\
\text { Di Tag ke } \\
\text { sensor }\end{array}$ & $\begin{array}{l}\text { Alat dapat } \\
\text { membaca } \\
\text { kartu Rfid }\end{array}$ & $\begin{array}{l}\text { Aplikasi } \\
\text { menampilkan } \\
\text { Kartu belum } \\
\text { terdaftar }\end{array}$ & Diterima \\
\hline 2. & $\begin{array}{l}\text { Menginput } \\
\text { Kartu } \\
\text { Belum } \\
\text { Terdaftar } \\
\text { Ke } \\
\text { Database }\end{array}$ & $\begin{array}{l}\text { Alat dapat } \\
\text { mendaftarkan } \\
\text { dan } \\
\text { menyimpan } \\
\text { kartu id ke } \\
\text { database }\end{array}$ & $\begin{array}{l}\text { Aplikasi } \\
\text { dapat } \\
\text { mendaftarkan } \\
\text { Kartu id dan } \\
\text { menyimpan } \\
\text { ke database }\end{array}$ & Diterima \\
\hline 3 & $\begin{array}{l}\text { Mengedit } \\
\text { data yang } \\
\text { di pilih }\end{array}$ & $\begin{array}{l}\text { alat dapat } \\
\text { mengedit } \\
\text { data yang di } \\
\text { pilih }\end{array}$ & $\begin{array}{l}\text { Aplikasi } \\
\text { dapat } \\
\text { mengedit } \\
\text { data yang di } \\
\text { pilih }\end{array}$ & Diterima \\
\hline 4 & $\begin{array}{l}\text { Menghapus } \\
\text { kartu yang } \\
\text { sudah } \\
\text { terdaftar }\end{array}$ & $\begin{array}{l}\text { Alat dapat } \\
\text { menghapus } \\
\text { kartu yang } \\
\text { sudah } \\
\text { terdaftar }\end{array}$ & $\begin{array}{l}\text { Aplikasi } \\
\text { dapat } \\
\text { menghapus } \\
\text { kartu yang } \\
\text { sudah } \\
\text { terdaftar }\end{array}$ & Diterima \\
\hline
\end{tabular}

TABEL IV. PENGUJIAN FORM KUNJUNGAN

\begin{tabular}{cllll}
\hline Percobaan & Jenis & Yang & Pengamatan & Hasil \\
& Pengujian & diharapkan & & \\
\hline 1 & Rfid Card & Alat dapat & Aplikasi dapat & Diterima \\
& terdaftar & mendeteksi & menampilkan & \\
& di tag ke & Kartu yang & pengunjung & \\
& sensor & terdaftar & masuk & \\
& (Masuk) & & datakunjungan & \\
\hline
\end{tabular}

\begin{tabular}{lllll}
\hline 2 & Rfid Card & Alat dapat & Aplikasi dapat & Diterima \\
terdaftar & mendeteksi & menampilkan & \\
di tag ke & Kartu yang & pengunjung & \\
sensor & sudah & keluar & \\
& (Keluar) & terdaftar & perpustakaan & \\
\hline
\end{tabular}

TABEL V. PENGUJIAN FORM EXPORT EXCEL

\begin{tabular}{|c|c|c|c|c|}
\hline Percobaan & $\begin{array}{l}\text { Jenis } \\
\text { Pengujian }\end{array}$ & $\begin{array}{l}\text { Yang } \\
\text { diharapkan }\end{array}$ & Pengamatan & Hasil \\
\hline 1 & $\begin{array}{l}\text { Button } \\
\text { Export di } \\
\text { tekan }\end{array}$ & $\begin{array}{l}\text { Sistem } \\
\text { dapat } \\
\text { merubah } \\
\text { database } \\
\text { kunjungan } \\
\text { ke file excel }\end{array}$ & $\begin{array}{l}\text { Sistem dapat } \\
\text { merubah ke } \\
\text { file Excel }\end{array}$ & Diterima \\
\hline 2 & $\begin{array}{l}\text { Button } \\
\text { Export di } \\
\text { tekan }\end{array}$ & $\begin{array}{l}\text { Sistem } \\
\text { berhasil } \\
\text { menyimpan } \\
\text { file ke } \\
\text { bentuk } \\
\text { excel }\end{array}$ & $\begin{array}{l}\text { Sistem dapat } \\
\text { menyimpan } \\
\text { file berupa } \\
\text { excel }\end{array}$ & Diterima \\
\hline
\end{tabular}

TABEL VI. PENGUJIAN LCD

\begin{tabular}{|c|c|c|c|c|}
\hline Percobaan & $\begin{array}{l}\text { Jenis } \\
\text { Pengujian }\end{array}$ & $\begin{array}{l}\text { Yang } \\
\text { diharapkan }\end{array}$ & Pengamatan & Hasil \\
\hline 1 & $\begin{array}{l}\text { Saat card } \\
\text { Id di } \\
\text { dekatkan } \\
\text { sensor } \\
\text { RFID }\end{array}$ & $\begin{array}{l}\text { Alat dapat } \\
\text { menampilka } \\
\mathrm{n} \\
\text { mendeteksi } \\
\text { kartu saat } \\
\text { masuk }\end{array}$ & $\begin{array}{l}\text { Aplikasi } \\
\text { dapat } \\
\text { menampilkan } \\
\text { pemberitahua } \\
\text { n di lcd }\end{array}$ & Diterima \\
\hline 2 & $\begin{array}{l}\text { Saat kartu } \\
\text { id di } \\
\text { dekatkan } \\
\text { sensor } \\
\text { RFID }\end{array}$ & $\begin{array}{l}\text { Alat dapat } \\
\text { menampilkan } \\
\text { pemberitahuan } \\
\text { di Lcd ketika } \\
\text { mendeteksi } \\
\text { kartu saat } \\
\text { keluar }\end{array}$ & $\begin{array}{l}\text { Aplikasi } \\
\text { dapat } \\
\text { menampilkan } \\
\text { pemberitahua } \\
\text { n keluar di } \\
\text { lcd }\end{array}$ & Diterima \\
\hline
\end{tabular}

TABEL VII. PENGUJIAN LED

\begin{tabular}{cllll}
\hline Percobaan & $\begin{array}{l}\text { Jenis } \\
\text { Pengujian }\end{array}$ & $\begin{array}{l}\text { Yang } \\
\text { diharapkan }\end{array}$ & Pengamatan & Hasil \\
\hline 1 & $\begin{array}{l}\text { Saat card } \\
\text { Id di } \\
\text { dekatkan }\end{array}$ & $\begin{array}{l}\text { Alat dapat } \\
\text { menyala } \\
\text { ketika }\end{array}$ & $\begin{array}{l}\text { Aplikasi } \\
\text { dapat }\end{array}$ & Diterima \\
& menyalakan & \\
& RFID & mendeteksi & led ketika & \\
& & masuk & mendeteksi & \\
& & kartu saat & \\
& Saat card & Alat dapat & Aplikasi & Diterima \\
& Id di & menyala & dapat & \\
ketika & menyalakan & \\
& dekatkan & mendeteksi & led ketika & \\
sensor & kartu saat & mendeteksi & \\
& RFID & keluar & kartu saat & \\
& & & masuk & \\
& & & & \\
& & & &
\end{tabular}

TABEL VIII. PENGUJIAN BUZZER

\begin{tabular}{lllll}
\hline Percobaan & $\begin{array}{l}\text { Jenis } \\
\text { Pengujian }\end{array}$ & $\begin{array}{l}\text { Yang } \\
\text { diharapkan }\end{array}$ & Pengamatan & Hasil \\
\hline $\mathbf{1}$ & Kartu & Alat dapat & Aplikasi & Diterima \\
& Rfid di & mengeluarkan & dapat & \\
dekatkan & suara saat & menyalakan & \\
& dengan & mendeteksi & buzzer & \\
& Sensor & kartu rfid & ketika & \\
\hline
\end{tabular}




\begin{tabular}{lllll}
\hline & $\begin{array}{l}\text { RFID } \\
\text { yang } \\
\text { sudah } \\
\text { terdaftar } \\
\text { (masuk) }\end{array}$ & $\begin{array}{l}\text { yang sudah } \\
\text { terdaftar }\end{array}$ & $\begin{array}{l}\text { mendeteksi } \\
\text { kartu }\end{array}$ & \\
& & & \\
\hline Kartu & Alat dapat & Aplikasi & Diterima \\
Rfid di & mengeluarkan & dapat & \\
dekatkan & suara saat & menyalakan & \\
dengan & mendeteksi & buzzer \\
ketika & \\
Sensor & kartu rfid & mendeteksi & \\
RFID & yang sudah & kartu & \\
yang & terdaftar & & \\
sudah & & & \\
terdaftar & & & \\
(keluar) & & \\
\hline
\end{tabular}

Masalah utama dalam pembuatan sistem ini adalah harus dilakukan pengkoneksian secara manual ke internet.

Keunggulan dalam penelitian ini telah mengatasi kekurangan-kekurangan yang terjadi, diantaranya:

a. Media dapat di akses dimana saja dengan terkoneksi internet.

b. Memudahkan dalam pengisian data kunjungan perpustakaan.

c. Tidak memerlukan koneksi internet yang super cepat tapi hanya memerlukan koneksi yang stabil.

d. Teknologi Internet of Things yang digunakan pada penelitian ini terbukti mampu mendukung komunikasi jarak jauh.

Penggunaan kartu RFID dan RFID reader dalam proses data kunjungan dapat lebih efektif dan efisien dalam proses otomatisasi pengisian data kunjungan perpustakaan.

\section{KESIMPULAN}

Teknologi RFID untuk otomatisasi data kunjungan perpustakaan dapat menjadi perkembangan dari Qrcode, perubahan yang semakin baik di dukung dengan sulitnya menduplikasi kartu RFID dengan terintegrasi Internet Of Things (IoT) memungkinkan pengguna dapat menyimpan alat dengan mudah.

Teknologi RFID untuk otomatisasi data kunjungan perpustakaan dapat menjawab kelemahan-kelemahan yang telah diteliti sebelumnya serta dapat dengan mudah digunakan oleh pengguna. Aplikasi ini telah diuji dan diimplemtasikan sehingga dapat digunakan dimana pengguna hanya perlu mengkoneksikan alat ini dengan internet.

\section{DAFTAR PUSTAKA}

[1] Widyawati, Ria. 2013. "Pengembangan Sistem Informasi Manajemen Perpustakaan Menggunakan Barcode dan Visual Basic". Thesis. Universitas Muhammadiyah Surakarta : Surakarta.

[2] Perwira, Husain Nanda. 2016. "Pengembangan Sistem Informasi Perpustakaan Berbasis Web". Skripsi. Teknik Informatika. UNY : Yogyakarta.
[3] Fitriyan, M Ramadhan. 2017. "Sistem Informasi Pengelolaan Perpustakaan Berbasis QRCode". Skripsi. Teknik Informatika. UNY : Yogyakarta.

[4] K. Ashton, "That 'Internet of Things' Thing : In the Real World Things Matter More than Ideas. RFiD Journal, vol. 22, pp. 97-114, 2009.

[5] Bafadal Ibrahim. (2014). "Pengelolaan Perpustakaan Sekolah”. Jakarta: Bumi Aksara.

[6] Munir dan Wawan. (2006), "Pengantar Sistem Informasi", Graha Ilmu, Yogyakarta.

[7] Kania, Widiyati. 2011. "Pengukuran Tingkat Kemapanan Penerapan Teknologi RFID di Perpustakaan Nasional RI Berdasarkan Framework Cobit4.1". Tesis Sekolah Pascasarjana Institut Pertanian Bogor. Bogor.

[8] Prakananda, M. (2012). "Rancangan Penerapan Teknologi RFID untuk Mendukung Proses Indentifikasi Dokumen dan Kendaraat di Samsat". Seminar Nasional Aplikasi Sains \& Teknologi (SNAST) III. Yogyakarta.

[9] Rachmat, H. H., \& Hutabarat, G. A. (2014). Pemanfaatan Sistem RFID sebagai Pembatas Akses Ruangan. Jurnal ELKOMIKA, 2(1), 27- 39.

[10] Setiawan, E. B., \& Kurniawan, B. (2015). Perancangan Sistem Absensi Kehadiran Perkuliahan dengan Menggunakan Radio Frequency Identification (RFID). Jurnal CoreIT, 1(2), 44-49. 